\title{
CASE REPORT OF BECKWITH-WIEDEMANN SYNDROME
}

Ravikanth Kㄴ, G. Somaiah², G. Anusha ${ }^{3}$, D. V. Umesh Reddy ${ }^{4}$, R. Naveen Reddy ${ }^{5}$

\section{HOW TO CITE THIS ARTICLE:}

Ravikanth K, G. Somaiah, G. Anusha, D. V. Umesh Reddy, R. Naveen Reddy. "Case Report of BeckwithWiedemann Syndrome". Journal of Evolution of Medical and Dental Sciences 2014; Vol. 3, Issue 23, June 09; Page: 6287-6290, DOI: $10.14260 /$ jemds/2014/2737

ABSTRACT: In 1963 Beckwith presented a report on the first patient with extreme cytomegaly of adrenal cortex, hyperplasia of kidneys as well as pancreas and Leydig cell hyperplasia. Wiedemann completed description of the new syndrome by adding umbilical hernia and macroglossia. The diagnosis is made based on the clinical signs of omphalocele.[7] or some other umbilical deformity, macroglossia. ${ }^{[8]}$ congenital asymmetry, visceromegaly (liver, pancreas, and kidneys). Newborn with macrosomia, macroglossia first differential diagnosis are infant of diabetic mother, congenital hypothyroidism etc. IDM can be identified easily with history of maternal diabetes. So congenital hypothyroidism is next common diagnosis and will be treated as hypothyroidism. If TSH, T3 and T4 are not clearly indicative of congenital hypothyroidism next consider the Beckwith Wiedemann syndrome in differential diagnosis of large for gestational age.

KEYWORDS: Macroglossia, Beckwith Wiedemann syndrome, glossectomy.

INTRODUCTION: Beckwith-Wiedemann Syndrome (BWS) ${ }^{[9]}$ is an overgrowth, multigenic disorder caused by dysregulation of the expression of imprinted genes in the $11 \mathrm{p} 15$ chromosomal region.[11,12] It is characterized by Omphalocele.[7], Gigantism, macroglossia, microcephaly and visceromegaly.[1] In an attempt to standardize the classification of BWS,[9] De Baun et al. have defined a child as having BWS if the child has at least two of the five common features (macroglossia, macrosomia, midline abdominal wall defects, ear creases/ear pits, neonatal hypoglycemia.[2]

Another definition presented by Elliot et al. includes the presence of either three major features (anterior abdominal wall defect, macroglossia, ${ }^{[8]}$ or prepostnatal overgrowth) or two major plus three minor findings (ear creases and pits, facial nevus flammeus, neonatal hypoglycemia,,13] nephromegaly, ${ }^{[10]}$ or Hemihyperplasia, embryonal tumors, polyhydramnios).[3]

CASE REPORT: A 4years-old female child presented to Pediatric outpatient of Mamata Medical College with the chief complaints of abdominal distension for the last 3 months, mass per abdomen for 4 days. She was apparently normal 3 months back when the parents noticed abdominal distension which was gradually increasing. Instinctly child's father noticed mass in the abdomen 4 days back on palpation. There was no history of constipation.

History of loss of appetite and weight loss present. This child is a product of nonconsanguineous marriage, full term, delivered by cesarian section because of a very bad obstetric history. Child of $10^{\text {th }}$ pregnancy, $1^{\text {st }}$ live child. Birth weight $4.35 \mathrm{kgs}$, motor milestones delayed. On examination she was well built, large tongue with mouth open all the time (Figure 1). Her height $104 \mathrm{cms}$ expected $100 \mathrm{cms}$. weight $20 \mathrm{kgs}$ expected $16 \mathrm{kgs}$. MAC $18 \mathrm{cms}$. 


\section{CASE REPORT}

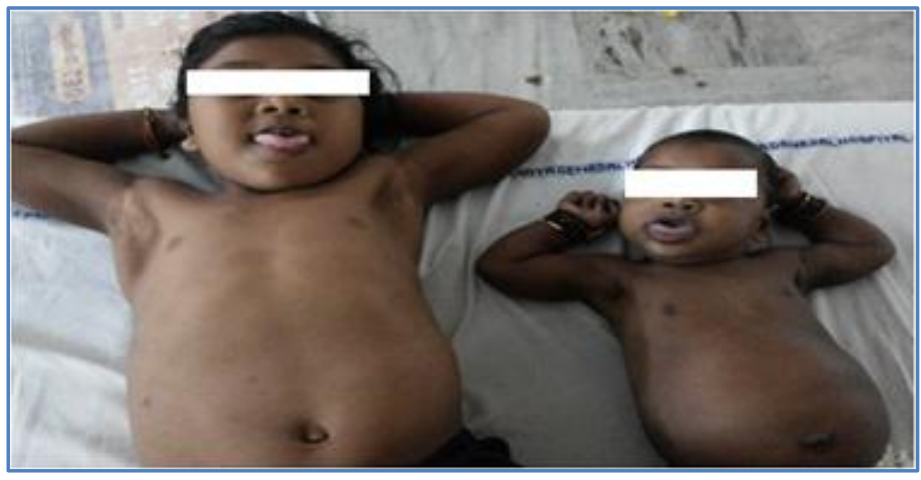

Figure 1: Siblings with large tongue and coarse features

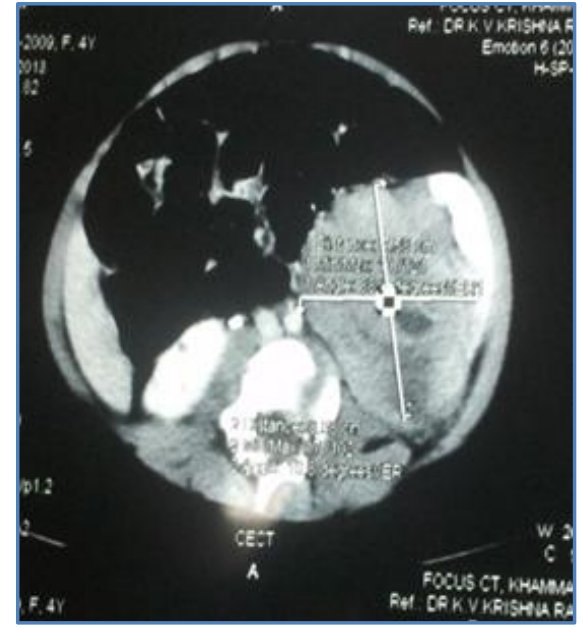

Figure 2: CECT Abdomen showing large heterogenous mass lesion from left kidney

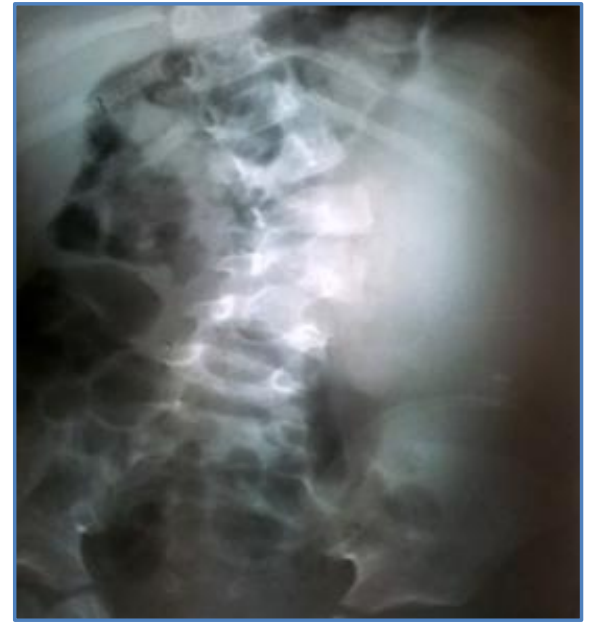

Figure 3: Plain X-Ray KUB showing enlarged left kidney

Systemic Examination: Per abdomen examination revealed a smooth, non-tender, large mass with ill-defined borders occupying most of the left lumbar and hypochondriac regions. Hepatomegaly present, diastasis recti present. Respiratory, cardiovascular \& central nervous systems appeared normal. Routine investigations $\mathrm{CBC}$, CUE, chest X ray were normal except platelet count 6lakhs/ cumm; X-Ray KUB plain suggesting enlarged left kidney (Figure 3). Abdominal ultrasonogram showing: 1. Mild hepatomegaly 2. Large heterogenous mass lesion (12.1 X 8.5 X 7.8cms) involving left lumbar \& iliac fossa regions 3. Left mild hydronephrosis. IVU \& CECT Abdomen were suggesting Nephroblastoma (figure 2). Chromosomal Analysis by Karyotyping showed normal female karyotype46, XX. The above described clinical features and investigations are suggestive of BeckwithWiedemann syndrome. Due to financial constraints, genetic and molecular studies could not be performed.

DISCUSSION: BWS[9] incidence is 1 in 13, 700 about 300 children with BWS[9] are born each year in the United States.[4] However, the exact incidence of BWS is unknown because of the marked variability in the syndrome presentation and difficulties with diagnosis. $>85 \%$ cases of BWS are 
sporadic, remaining $<15 \%$ cases of BWS are familial. BWS[9] can be caused by a range of different genetic defects. These include cytogenetic abnormalities, genetic abnormalities [11p 15[11,12] paternal uniparental disomy (UPD), mutations in the CDKN1C gene], epigenetic abnormalities [H19 gene, KCNQ10T1 gene \& microdeletions within IC1 or IC2. 7.5 to $10 \%$ of BWS patients will develop tumor.

Wilm's tumor is the most common embryonal tumor in patients with BWS followed by hepatoblastoma.[5] children with BWS[9] are also at increased risk of developing adrenal cortical carcinoma, neuroblastoma, and rhabdomyosarcoma. Wilms tumor and hepatoblastoma can usually be cured if diagnosed early. All children with BWS ${ }^{[9]}$ should receive cancer screening. An abdominal ultrasound every 3 months ${ }^{[6]}$ until at least eight years of age is recommended and a blood test to measure alpha-fetoprotein (AFP) every 6 weeks until at least four years of age. Prognosis is good in these cases.

Our case was not diagnosed as a case of BWS[9] till 4 years of age and hence regular screening was not carried out. Child presented with wilms tumor. She was kept on chemotherapy for wilms tumor.

As child was having large tongue with open mouth and macrosomia child was misdiagnosed as congenital hypothyroidism and was kept on thyroxine from $10^{\text {th }}$ day of life in a private hospital.

In conclusion, early recognition of BWS[9] is important because of its associated risk of malignancy. Prognosis for long term survival is good if these children are identified early and appropriately screened for malignancy

\section{REFERENCES:}

1. Mark. A. Sperling, Genetic disorders of Metabolism. Hypoglycemia: Nelson Textbook of Pediatrics, $19^{\text {th }}$ edition: 517-529.

2. De Baun MR, Niemitz EL, McNeil DE, Brandenburg SA, Lee MP, Feinberg AP (March 2002). "Epigenetic alterations of H19 and LIT1 distinguish patients with Beckwith-Wiedemann syndrome with cancer and birth defects". American Journal of Human Genetics 70 (3): 604-11.

3. Elliott M, Bayly R, Cole T, Temple IK, Maher ER (August 1994). "Clinical features and natural history of Beckwith-Wiedemann syndrome: presentation of 74 new cases". Clinical genetics 46(2): 168-74.

4. Thorburn MJ, Wright ES, Miller CG, Smith-Read EH (April 1970). "Exomphalos-macroglossiagigantism syndrome in Jamaican infants". American journal of diseases of children 119 (4): 316-21.

5. DeBaun MR, Tucker MA (March 1998). "Risk of cancer during the first four years of life in children from The Beckwith - Wiedemann Syndrome Registry". The Journal of pediatrics 132(3 Pt 1): 398-400.

6. Choyke PL, Siegel MJ, Craft AW, Green DM, DeBaun MR (March 1999). "Screening for Wilms tumor in children with Beckwith-Wiedemann syndrome or idiopathic hemihypertrophy".Medical and pediatric oncology 32 (3): 196-200.

7. Beckwith JB. Extreme cytomegaly of the adrenal fetal cortex, omphalocele, hyperplasia of the kidneys and pancreas and leydig cell hyperplasia-another syndrome? Presented at the Annual Meeting of Western Society for Pediatric Research Los Angeles, California, November 11, 1963.

8. Wiedemann HR. Complexe malformatif fami-lial avec hernie ombilicale et macroglossie "unsyndrome noveau?" J Genet Hum 1964; 13: 223-232. 
9. Sotelo-Avila C, Gonzalez-crussi F, Fowler JW. Complete and incomplete forms of BeckwithWiedemann syndrome: Their onco-genic potential. J Pediatr 1980; 96: 47-50.

10. Sotelo-Avila C, Gooch WM. Neoplasms associated with Beckwith-Wiedermann syn-drome. Perspect Pediatr Pathol 1976; 3: 255-272.

11. Sotelo-Avila C, Gooch WM. Neoplasms associated with Beckwith-Wiedermann syn-drome. Perspect Pediatr Pathol 1976; 3: 255-272.

12. Koufos A, Grundy P, Morgan K, Aleck KA, Hadro T, Lampkin BC, et al. Familial WiedemannBeckwith Syndrome and a second Wilm's tumor locus both map to 11p 15.5. Am J Hum Genet 1989; 44: 711-719.

13. Scott J, Cowell J, Robertson ME, Priestley LM, Wadey R, Hopkins B, et al. Insulin - like growth factor to gene expression in Wilm's tumor and embryonic tissues. Nature 1985; 317: 260-262.

\section{AUTHORS:}

1. Ravikanth K.

2. G. Somaiah

3. G. Anusha

4. D. V. Umesh Reddy

5. R. Naveen Reddy

\section{PARTICULARS OF CONTRIBUTORS:}

1. Post Graduate Student, Department of Paediatrics, Mamata Medical College \& General Hospital, Khammam, Andhra Pradesh.

2. Professor of Paediatrics \& Guide, Department of Paediatrics, Mamata Medical College \& General Hospital, Khammam, Andhra Pradesh.

3. Post Graduate Student, Department of Paediatrics, Mamata Medical College \& General Hospital, Khammam, Andhra Pradesh.

4. Post Graduate Student, Department of Paediatrics, Mamata Medical College \& General Hospital, Khammam, Andhra Pradesh.
5. Post Graduate Student, Department of Paediatrics, Mamata Medical College \& General Hospital, Khammam, Andhra Pradesh.

\section{NAME ADDRESS EMAIL ID OF THE CORRESPONDING AUTHOR:}

Dr. Ravikanth K, Mamata Medical College \& General Hospital, Khammam, Andhra Pradesh.

Email: kanthmedico@gmail.com

Date of Submission: 22/05/2014.

Date of Peer Review: 23/05/2014.

Date of Acceptance: 26/05/2014.

Date of Publishing: 03/06/2014. 